TITLE:

\title{
A NEW AMPHIPOD OF THE GENUS SIPHONOECETES FROM THE SHALLOW BOTTOM OF SOUTHERN JAPAN, WITH REFERENCE TO THE DIAGNOSES OF THE GENUS AND ITS SPECIES
}

\section{$\operatorname{AUTHOR}(\mathrm{S})$ :}

Harada, Eiji

\section{CITATION:}

Harada, Eiji. A NEW AMPHIPOD OF THE GENUS SIPHONOECETES FROM THE SHALLOW BOTTOM OF SOUTHERN JAPAN, WITH REFERENCE TO THE DIAGNOSES OF THE GENUS AND ITS SPECIES. PUBLICATIONS OF THE SETO MARINE BIOLOGICAL LABORATORY 1971, 18(6): $355-378$

\section{ISSUE DATE:}

\section{1-03-31}

URL:

http://hdl.handle.net/2433/175653

RIGHT: 


\title{
A NEW AMPHIPOD OF THE GENUS SIPHONOECETES FROM THE SHALLOW BOTTOM OF SOUTHERN JAPAN, WITH REFERENCE TO THE DIAGNOSES OF THE GENUS AND ITS SPECIES ${ }^{1 \text { ) }}$
}

\author{
EIJI HARADA \\ Biological Laboratory, Yoshida College, Kyoto University
}

With 11 Text-figures and 1 Table

\begin{abstract}
During the underwater observation on the association between a snapping shrimp Alpheus bellulus MryA and Mryake and gobioid fishes Amblyeleotris japonicus TAKAGI and Vireosa hanae JoRdAN et STARKs on the shallow coastal bottom in Tanabe Bay, I noticed the presence of large populations of an amphipod over the bottom. The amphipods were carrying with them the nests made of sand grains and tiny shells and were actively crawling around, that gave me at first sight an impression as if bottom sand were being stirred in motion by water movement due to the surf, which was instantly corrected by sighting the antennae extending out among the sand grains gathered. This amphipod was also found in the stomach of Amblyeleotris japonicus (HARADA, 1969). It was soon revealed by the examination of the specimens that the amphipod in question was a corophiid and, by closer study, was identified as a species of the genus Siphonoecetes which had not been recorded from the Japanese waters.

According to Barnard (1969), the genus Siphonoecetes comprises 9 species. This notion of him seems to be a revision of his list of 1958, which contains 10 species for the same genus, by taking into account Ruffo's opinion (1959). Distribution of the genus is known to extend from the arctic-boreal to suspectedly the antisubtropics and from the littoral to the bathyal water (565 metres deep) (BARNARD, 1969). If, however, the localities of occurrence of the species of the genus are examined through the records for each species, it is evidently indicated that the west Pacific, as well as the east Pacific and the wide range of the west Atlantic, has no representative species. And from the descriptions given there, it is also shown that the habit of inhabiting nest tubes or univalve shells, which are both frequently agglutinated with sand grains and shell fragments, is common among the species of the genus.
\end{abstract}

1) Contributions from the Seto Marine Biological Laboratory, No. 538.

Publ. Seto Mar. Biol. Lab., XVIII (6), 355-378, 1971. （Article 25) 
The present paper deals with the systematic and some biological accounts of this new amphipod, which apparently provides the first record of the genus Siphonoecetes in the subtropical north-western Pacific. The collections were made on the sublittoral bottoms along the coasts of Kii Peninsula, Shikoku and in Wakasa Bay to obtain any information on the geographical distribution of the species. The most intensive of quantitative collections were made underwater from populations at various depths and substrata in Tanabe Bay (Text-fig. 1) with the aid of a quadrate scoop designed to sample the surface of the bottom over an area of $5 \times 5 \mathrm{~cm}^{2}$ to a depth of about 0.5 $\mathrm{cm}$ by hand. The substrata sampled, after sorting the interstitial fauna out, were analysed of particle size. On the basis of these materials, population densities were calculated for each habitat.

I wish to thank Professor H. UTinomi and Dr. T. Tokioka for advice and criticism, and for affording me facilities of the Seto Marine Biological Laboratory. My thanks are also due to Dr. Isabella Gordon, Dr. K. Nagata and Dr. S. Nishimura, who have generously made some literatures available to me.

\section{Siphonoecetes tanabensis, n. sp.}

(Japanese name: Sunakudayadomushi)

(Text-figs. 3-9)

Material examined: More than a thousand individuals from Tanabe Bay, with some from off Nasa on the south-east coast of Shikoku, have been examined for the present study.

Description: Male slightly larger than female.

Colour pale gray with much spots, patches and bands of dark colour; particularly distinctly a dark brown area on the anterodorsal half of the head segment, a light brown area on the anterodorsal half of 2 nd body segment, a reddish brown band on the proximal end of 4th article of antenna II, on both ends of 2nd and 3rd articles of antenna $I$ and at the middle of flagellar articles of antenna $I$.

Body cylindrical and flattened ventrally. Head with rostrum which is normally sharply pointed in smaller individuals but is often blunt in larger individuals. Eyes composed of dark ocelli in the middle with 5 to 8 colourless ocelli on the periphery, situated on the antero-lateral projection, bearing 2 short setae on its apex, of the head. Pleon segments V and VI coalesed, at least dorsally. Telson entire, with a pair of spinulated plates near its posterior margin.

Antenna I shorter than antenna II, reaching to the middle of 5 th article of peduncle of antenna II; articles of peduncle of nearly equal length, of which 3rd article shortest; 1st article of peduncle broad; flagellum consisted of 6 articles, or quite rarely 7 , in full-grown individuals (about 2.5 to $2.8 \mathrm{~mm}$ in body length), or of 5 or 4 articles in most individuals which are matured but slightly smaller (about 1.5 


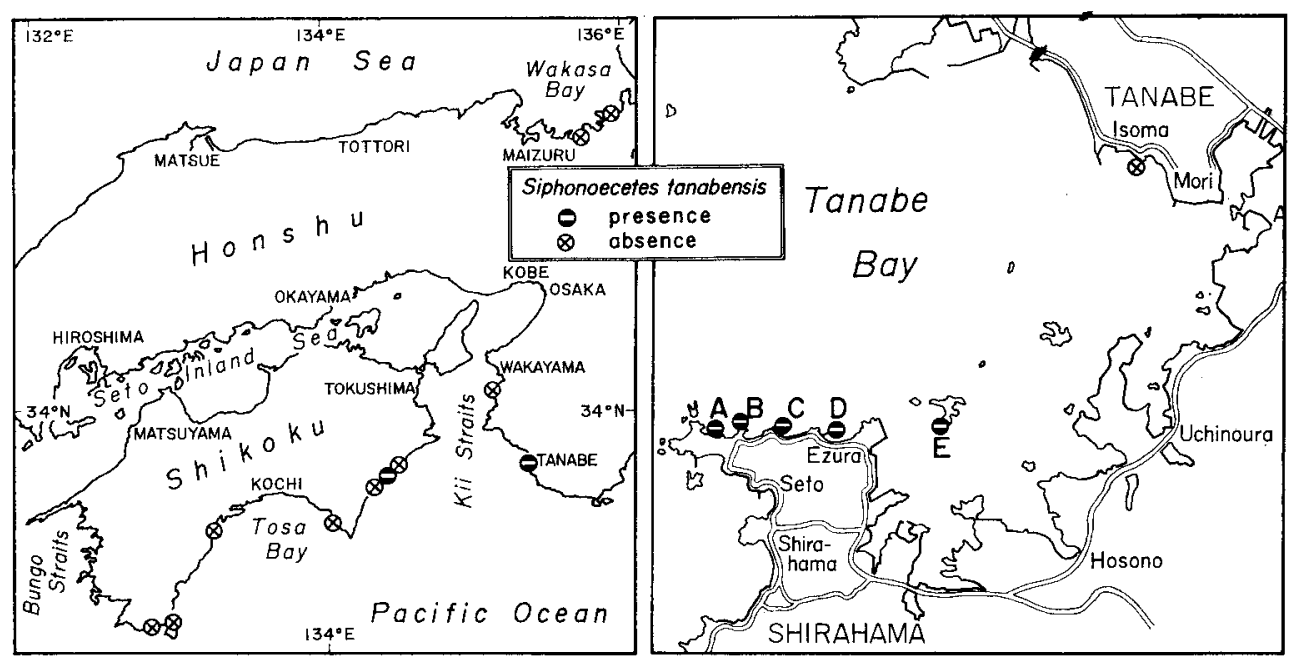

Text-fig. 1. Localities of collection and occurrence of Siphonoecetes tanabensis, n. sp., in southern Japan and stations for the study of its biology.

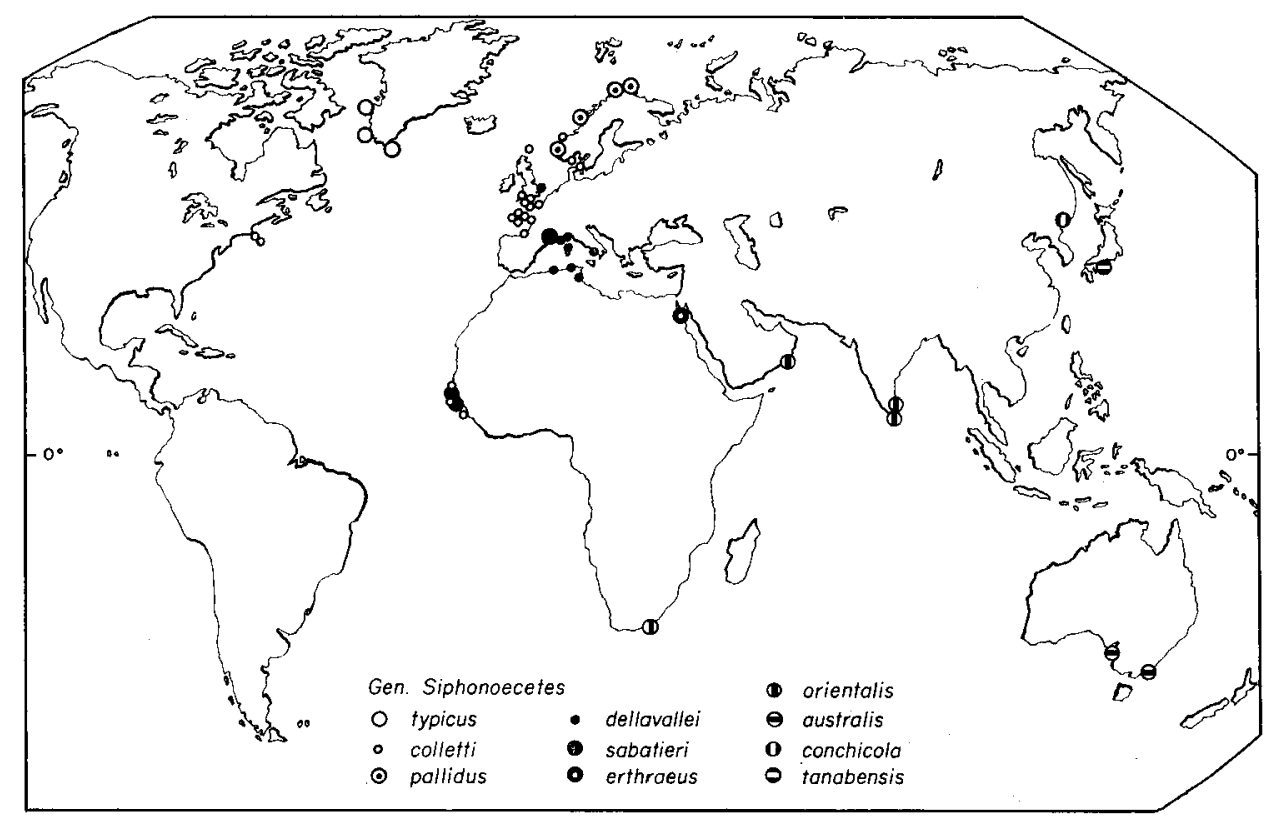

Text-fig. 2. Known distributions of the species of the genus Siphonoecetes. Note that the occurrence of $S$. colletti and $S$. pallidus along the south and the southern west coast of Norway is not given as actual site of collection recorded and that the identification of $S$. sabatieri occurred on the west coast of Africa is expressed as dubious by ReID (1951) himself. 


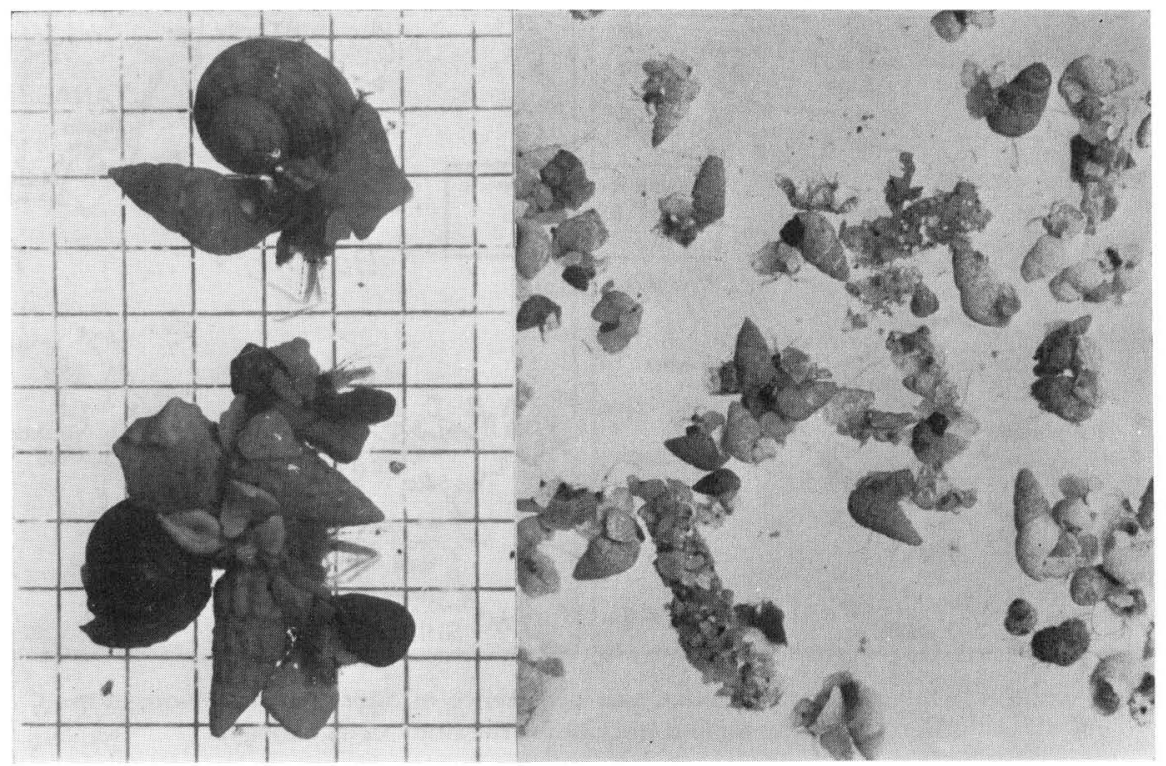

Text-fig. 3. Siphonoecetes tanabensis, n. sp., carrying their nests agglutinated with sand grains and shells. Left: fixed specimens, collected from off Rinkai, St. A, in August 1968. Right: alive specimens, collected from Hatakeiima, St. E, on 18 August, 1969.

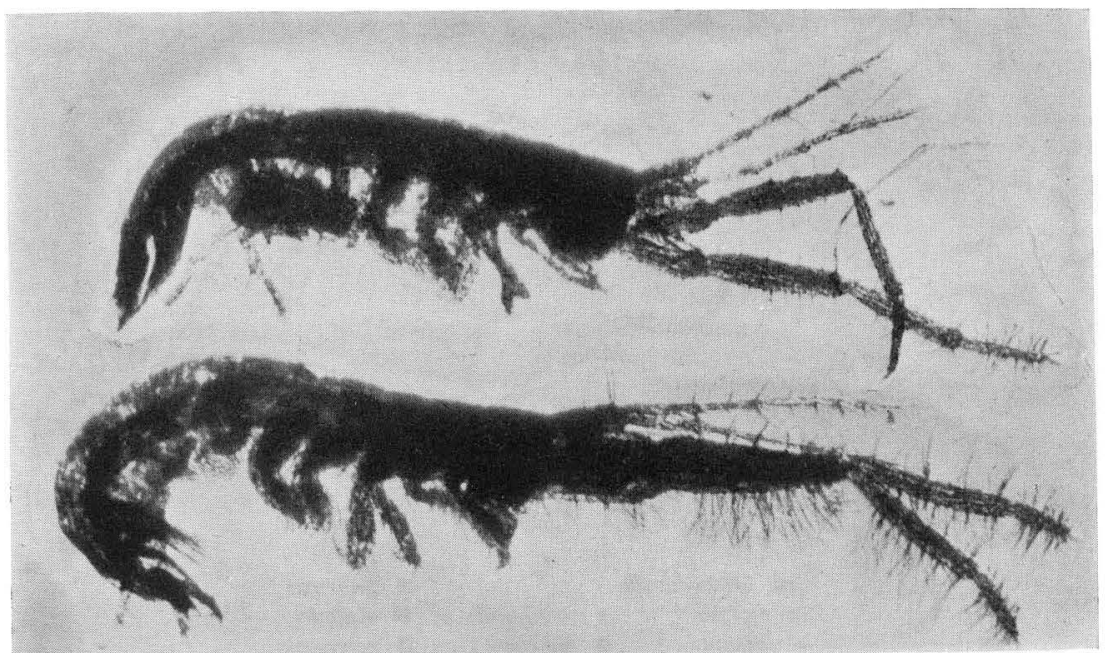

Text-fig. 4. Siphonoecetes tanabensis, n. sp., taken out from their nests. Above: female. Below: male. 
to $2.5 \mathrm{~mm}$ in body length) in both sexes (Text-fig. 9). Antenna II with stout peduncle, first two articles not distinct, 3rd article broad, 4th article longest and longer than the preceding three articles combined, 5th article nearly equal to the first three articles combined; flagellum of 4 articles and nearly equal to 5 th article of peduncle, distal two articles of flagellum very small, proximal two articles of nearly equal length, all articles of flagellum armed with bifurcate unguiform spines; these features of antenna II not distinctly different sexually.

Gnathopod I rather slender, 5th and 6th articles of nearly equal length, bearing tufts of long setae but no spine, 7th article with a series of deep indentations. Gnathopod II rather strong, 4th and 5 th articles small and of nearly equal size, both narrowing posteriorly to form projections armed with spines, palm of 6 th article slightly concave and armed with tufts of strong setae and 2 spines near the postero-proximal end, 7th article with a series of deep indentations on grasping margin.

Peraeopod I with cardioform 4th article, 5th article small, 7th article unguiform. Peraeopod II similar to peraeopod I. Peraeopod III with conical 5th article which is covered with spinules and 2 bifurcate spines, 7 th article hooked and bifurcate. Peraeopod IV very much like peraeopod III. Peraeopod V longest and slender, 4 th and 5th articles of equal length, 6th article about 1.3 times as long as 5th article, 7th article hooked and bifurcate as in peraeopods III and IV. Pleopods normal, basal parts expanding posteriorly, with hooked spines on their posterior margins.

Uropod I biramous, outer ramus slightly longer than the inner and armed dorsolaterally with 4 bifurcate strong spines and rows of spinules and with 1 strong and 2 or 3 terminal spines; inner ramus with 1 strong terminal spine; peduncle carrying 3 or 4 spines on its dorsal surface almost twice as long as outer ramus. Uropod II uniramous, peduncle bearing 1 spine on its dorsal surface close to its distal end twice as long as ramus bearing 1 strong terminal spine and spinules on its lateral surface. Uropod III uniramous, peduncle expanding strongly medially, without spines or setae and 1.4 times as long as ramus which is rather elongated and bearing setae and spines on the postero-lateral corner and spines on the postero-medial corner.

Relative lengths of articles of antennae are, from the results of morphometric analyses, not strictly held to throughout the growth. As is shown in Table I, although the ratio of length of peduncular article III to IV of antenna II is most stable to size and sex, the ratio of length of flagellar article II to I of antenna II decreases steadily as the animal grows, indicating that the length of flagellar article I increases much faster, in both sexes. The ratios of length of peduncular articles of antenna $I$ are more or less variable, although it appears that the ratio of length of peduncular article I to III in male decreases and that of peduncular article II to III increases in both sexes as the animal grows. The ratio of length of peduncular article $V$ to IV of antenna II is most fluctuating.

Number of eggs carried 1 to 3, usually 2. Ovigerous females occur in those with more than 4 flagellar articles on antenna I, and very seldom with 3 . 


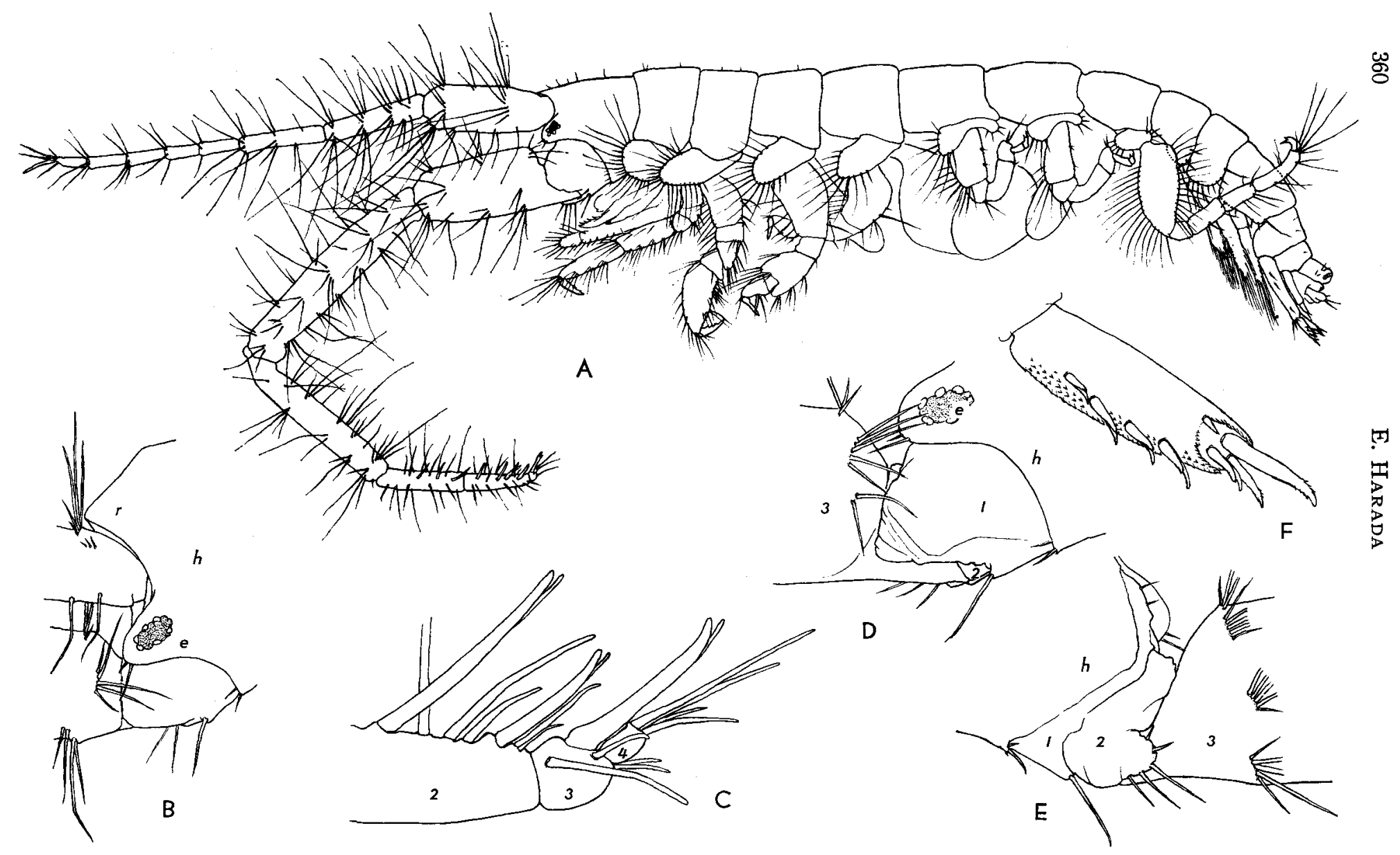

Text-fig. 5. Siphonoecetes tanabensis, n. sp. A, lateral view $(\times 53) ; \quad$, rostrum and lateral lobe with eye $(\times 88) ;$ C, distal articles of flagellum of antenna II $(\times 345)$; D, lateral view of proximal articles of peduncle of antenna II $(\times 134)$; E, medial view of proximal articles of peduncle of antenna II $(\times 134) ; \mathrm{F}$, dorsal view of outer ramus of uropod I $(\times 345)$. $e$, eye; $h$, head; $r$, rostrum; 1,1 st article; 2, 2nd article; 3, 3rd article; 4, 4th article. A-E, male, $2.4 \mathrm{~mm}$, and F, male, $2.3 \mathrm{~mm}$, $3.9 \mathrm{~m}$ deep, sandy bottom, off Rinkai, St. A, Tanabe Bay, 13 August, 1969. 

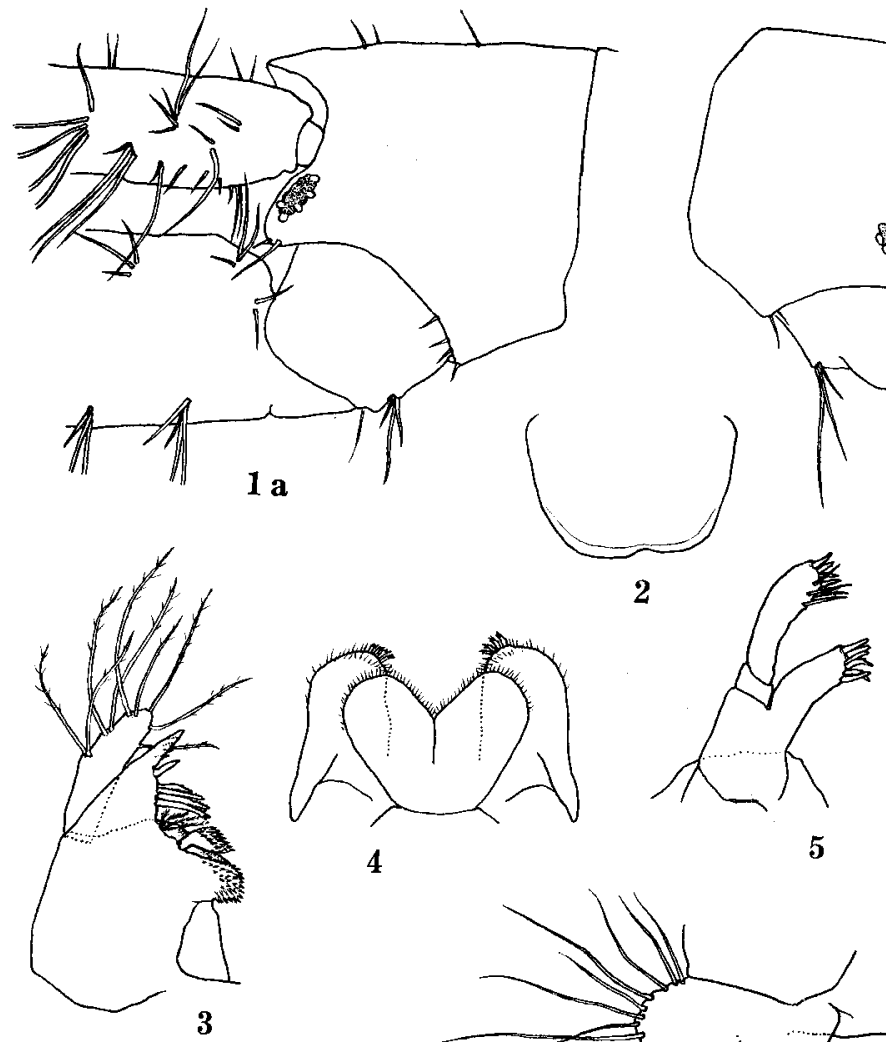

5

$1 \mathbf{b}$
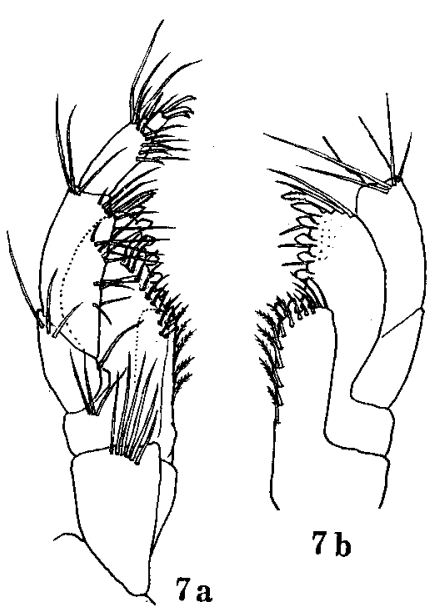

7 b
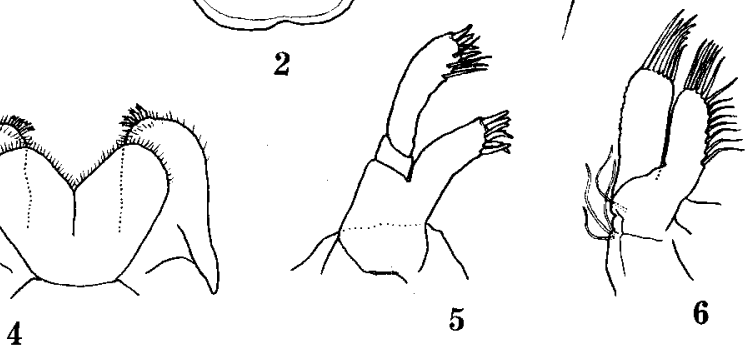

6
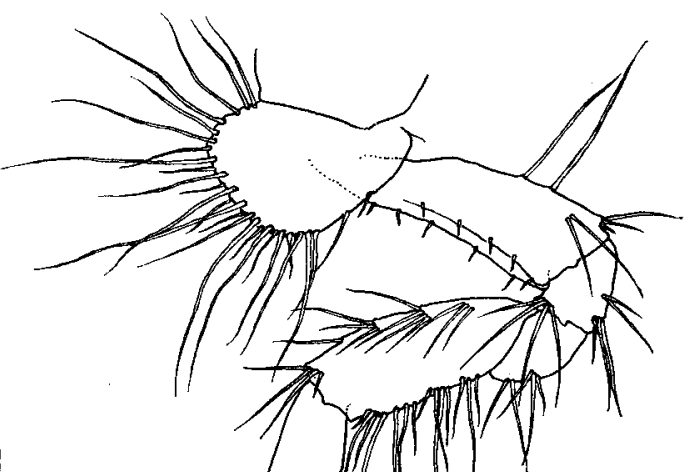

Text-fig. 6. Siphonoecetes tanabensis, n. sp. 1, head $(\times 82) ; 2$, upper lip $(\times 125) ; 3$, mandible $(\times 125) ; 4$, lower lip $(\times 125) ; 5$, maxilla I $(\times 125) ; 6$, maxilla II $(\times 125) ; 7$, maxilliped (b, the reverse side of $a ; \times 125) ; 8$, gnathopod $\mathrm{I}(\times 82)$. la, female, $2.5 \mathrm{~mm}$, and $1 \mathrm{~b}-7$, male, $2.3 \mathrm{~mm}, 3.9 \mathrm{~m}$ deep, sandy bottom, off Rinkai, St. A, Tanabe Bay, 13 August, 1969. 

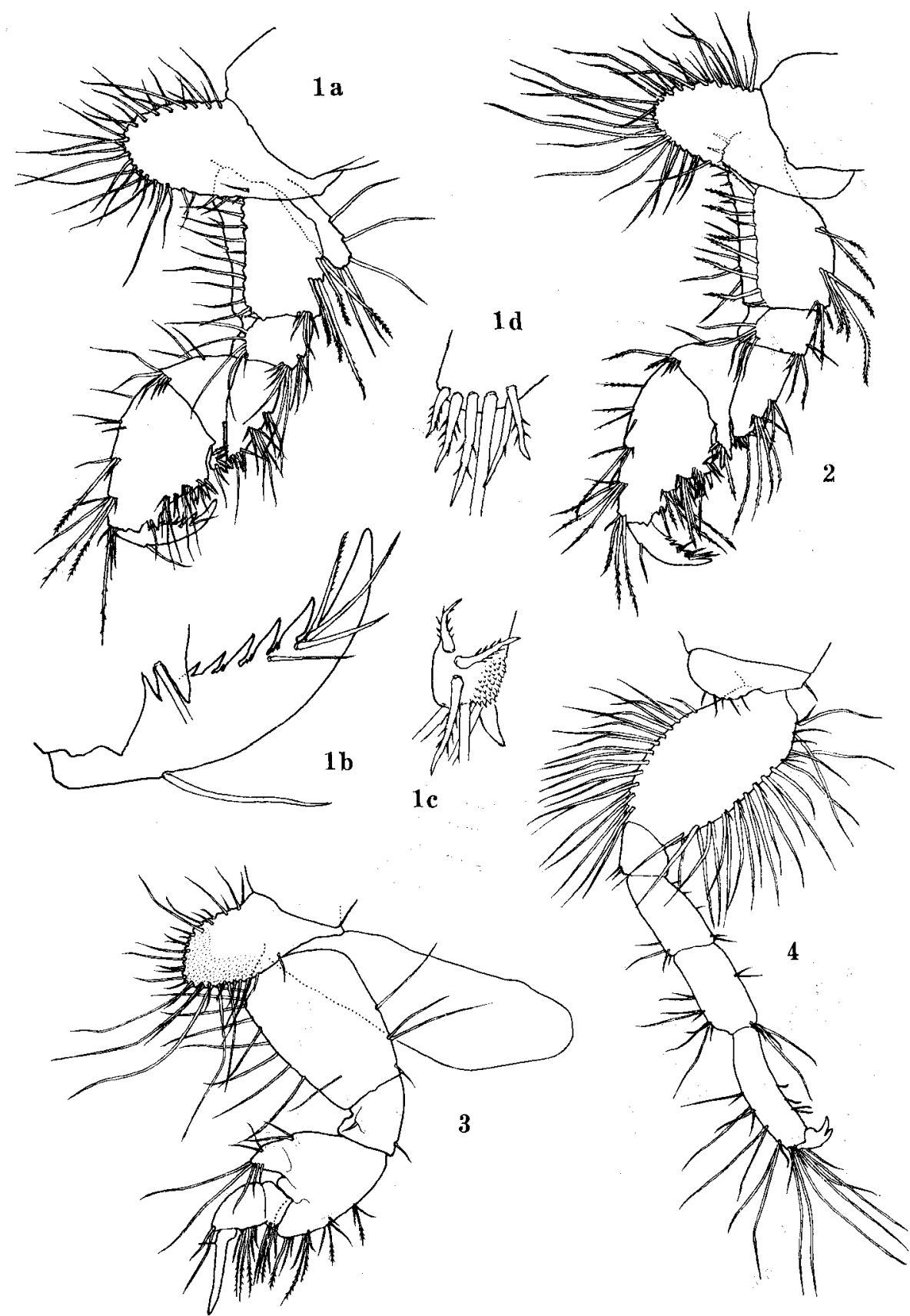

Text-fig. 7. Siphonoecetes tanabensis, n. sp. 1 \& 2, gnathopod II (b, 7th article; c, posterior projection of 5 th article; d, posterior projection of 4th article; 1 a \& $2, \times 82$, lb-1d, $\times 335)$; 3, peracopod I $(\times 82) ; 4$, peraeopod V $(\times 82)$. 1, female, 2.5 $\mathrm{mm}$, and $2-4$, male, $2.3 \mathrm{~mm}, 3.9 \mathrm{~m}$ deep, sandy bottom, off Rinkai, St. A, Tanabe Bay, 13 August, 1969. 


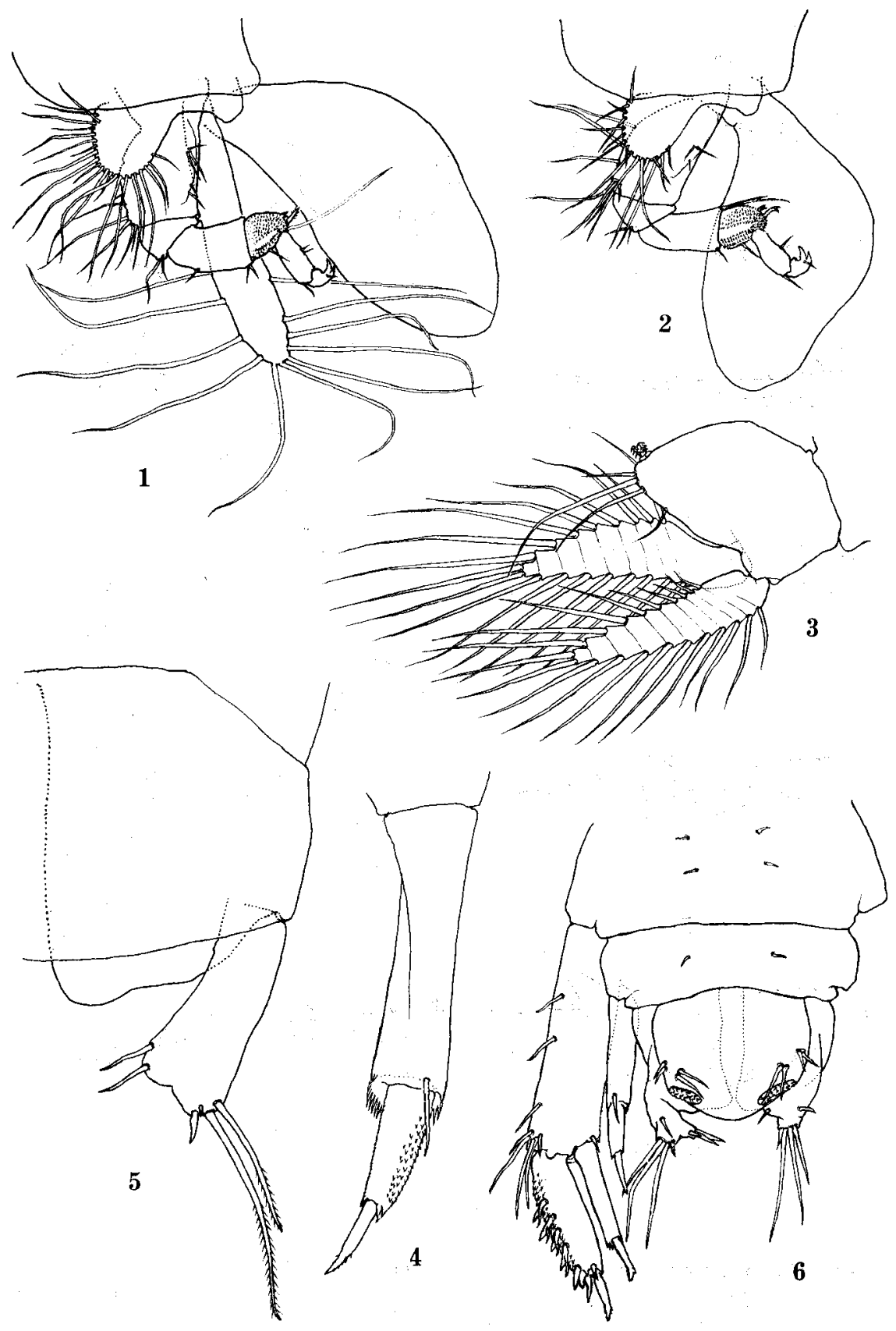

Text-fig. 8. Siphonoecetes tanabensis, n. sp. 1 \& 2, peraeopod III $(\times 82)$; 3, pleopod III $(\times 125) ; 4$, uropod II $(\times 335) ; 5$, uropod III $(\times 335) ; 6$, urosome, telson and uropod I ( $\times 125$ ). 1, female, $2.5 \mathrm{~mm}$, and $2-6$, male, $2.3 \mathrm{~mm}, 3.9 \mathrm{~m}$ deep, sandy bottom, off Rinkai, St. A, Tanabe Bay, 13 August, 1969. 

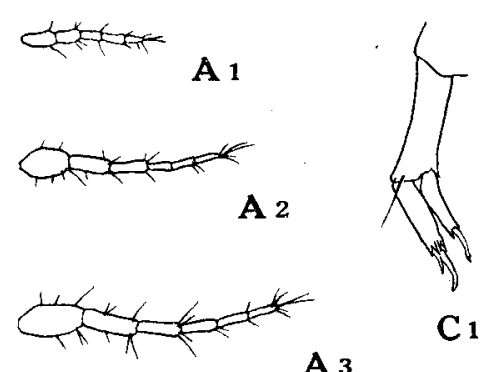

A. 3

C 1
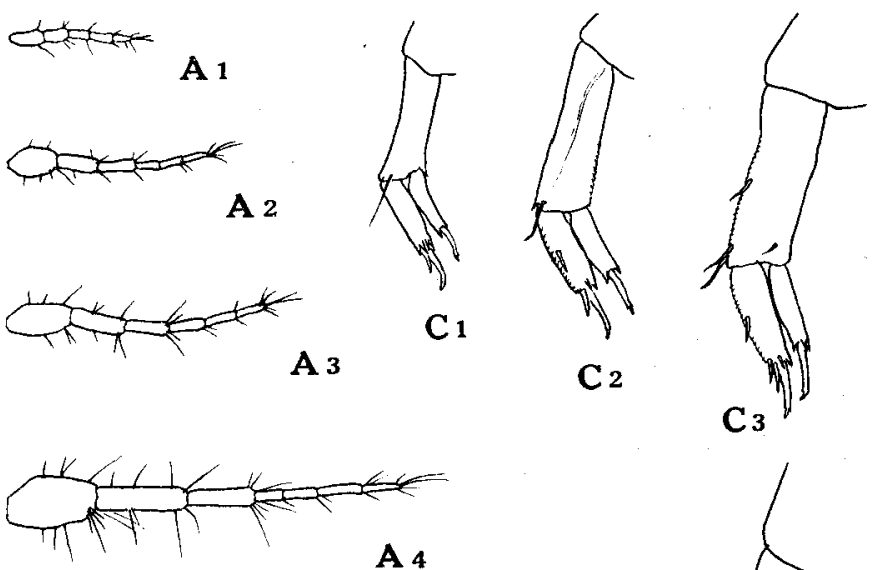

A 4

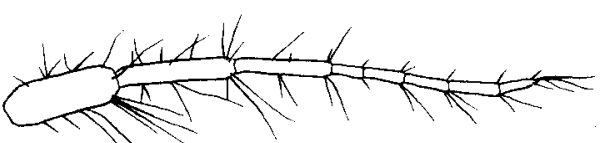

A 5

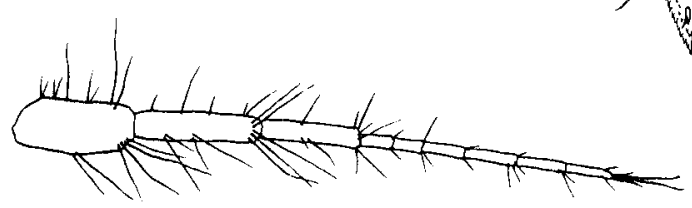

A 6
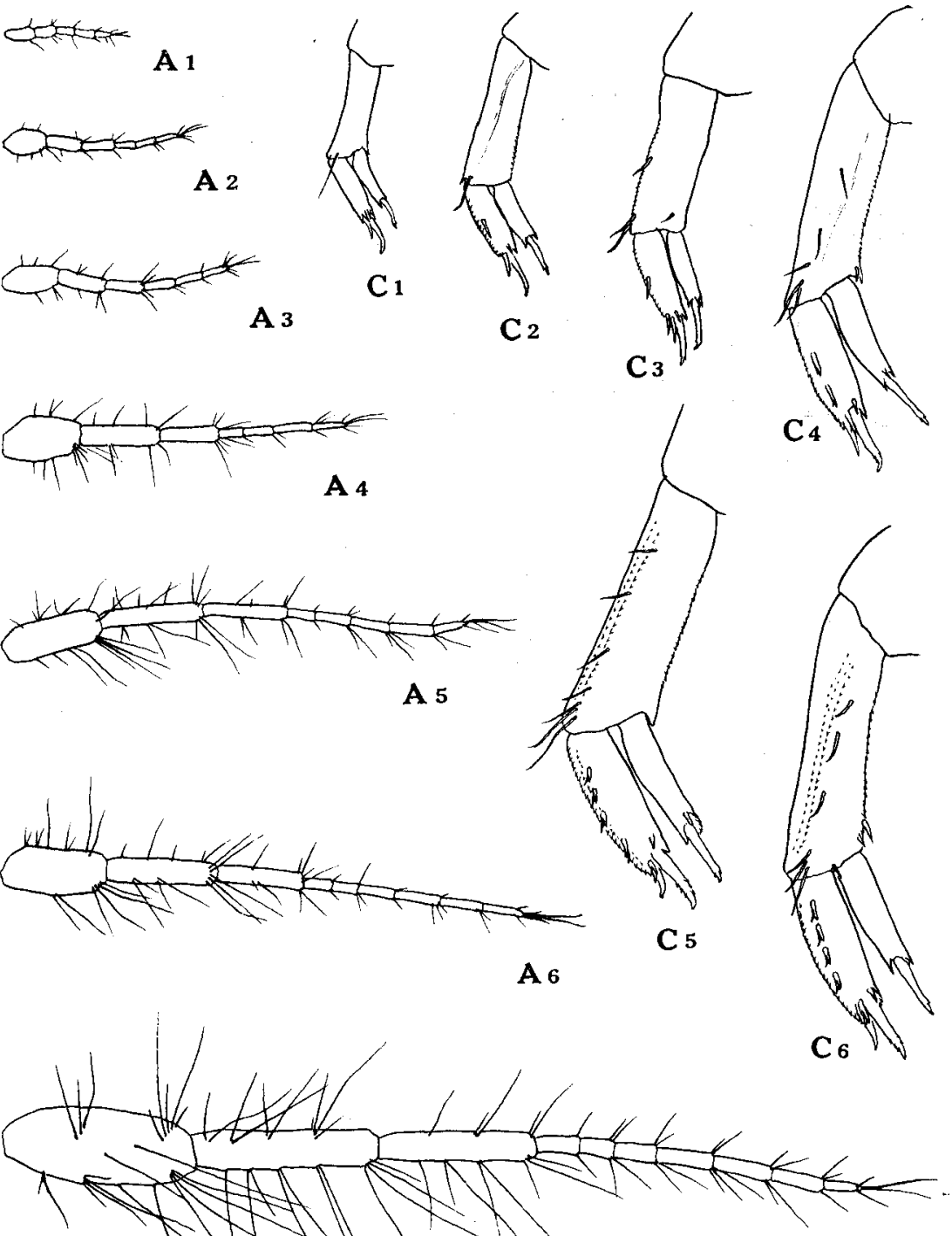

A 7

Text-fig. 9A. Siphonoecetes tanabensis, n. sp. Antenna $I(A, \times 45)$, antenna $11\left(B, \times 45 ; B_{1}\right.$ in part, $\times 345)$, uropod $\mathrm{I}(\mathrm{C}, \times 130)$ and uropod II $(\mathrm{D}, \times 130)$ at successive developmental stages. 1, juvenile, $0.78 \mathrm{~mm} ; 2$, juvenile, $1.13 \mathrm{~mm}$; 3, male, $1.40 \mathrm{~mm} ; 4$, male, $1.78 \mathrm{~mm}$; 5 , male, $2.15 \mathrm{~mm} ; 6$, male, $2.51 \mathrm{~mm} ; 7$, male, $3.27 \mathrm{~mm}$. All from sandy bottom, $3.9 \mathrm{~m}$ deep, off Rinkai, St. A, Tanabe Bay, 13 August, 1969. 
Holotype: Female, ovigerous, $2.5 \mathrm{~mm}$, collected off Rinkai, St. A, approximately 70 $\mathrm{m}$ off the northern shore of the Seto Marine Biological Laboratory, in Tanabe Bay at a depth of about $3.9 \mathrm{~m}$ on August 13, 1969; retained at the author's laboratory together with specimens of the type-series.

Type-locality: Off Rinkai, St. A, approximately $70 \mathrm{~m}$ off the northern shore of the Seto Marine Biological Laboratory, in Tanabe Bay, about $3.9 \mathrm{~m}$ in depth, sandy
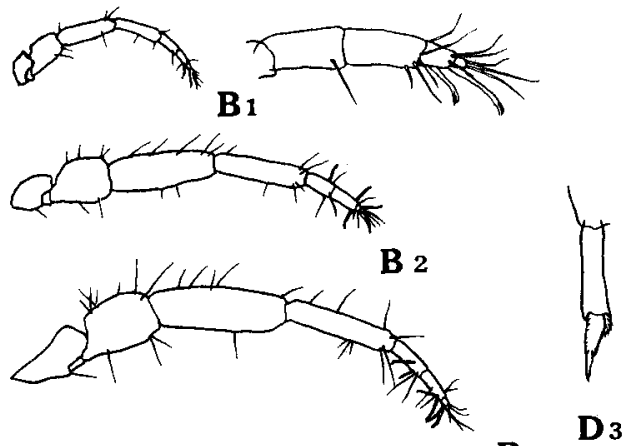

B 3
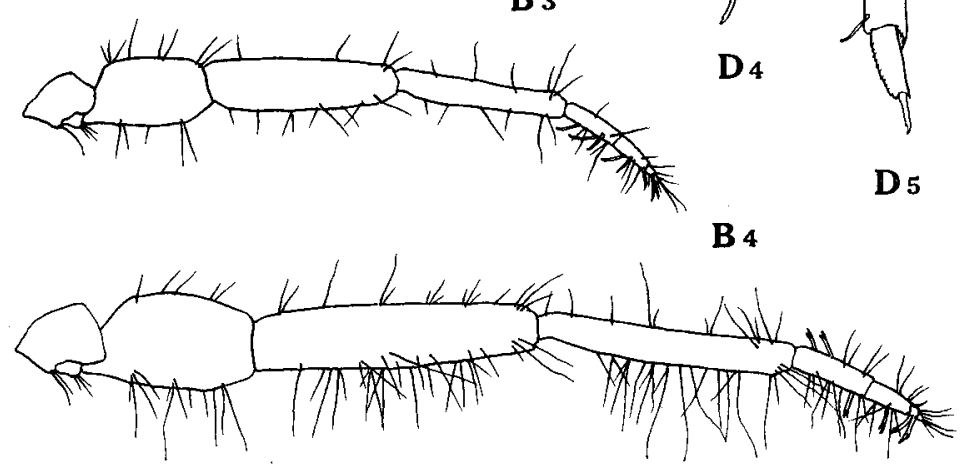

B 5

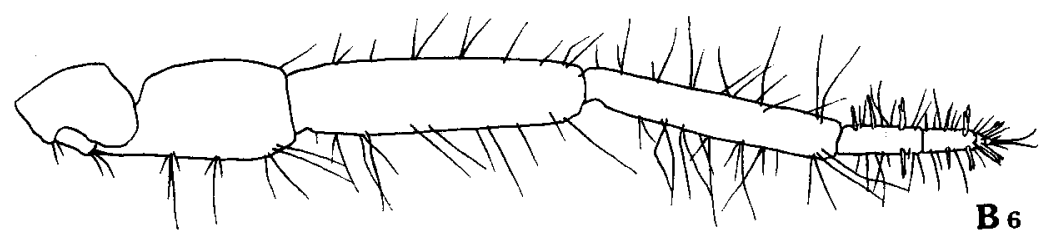

Text-fig. $9 \mathrm{~B}$.

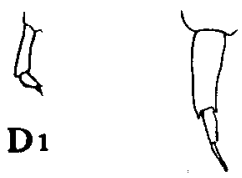

D 2

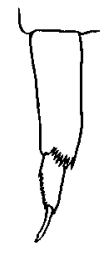

$\mathrm{D}_{4}$

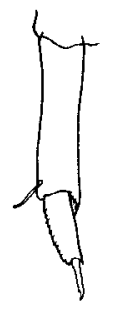

D 5

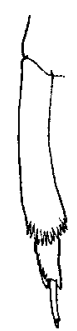

D 6

bottom with sparse growth of Zostera nana.

Distribution: The majority of the specimens of the present species have been collected from sandy bottoms, depths ranging from 0.5 to $5 \mathrm{~m}$, in the southern part of Tanabe Bay. Only a few specimens were captured on the sandy bottom among rocks, about $2.5 \mathrm{~m}$ in depth, some $10 \mathrm{~m}$ off the shore of Nasa, Shishikui, on the south-east coast of Shikoku. No specimen has been collected from the bottoms of southern coast of 
Table 1. The size and lengths of articles of antennae I and II for each group classed by sex and number of flagellar articles of antenna $I$.

\begin{tabular}{|c|c|c|c|c|c|c|c|c|c|c|c|c|c|}
\hline \multirow{4}{*}{ material } & \multirow{4}{*}{$\operatorname{sex}$} & \multirow{4}{*}{$\begin{array}{l}\text { number } \\
\text { of } \\
\text { flagellar } \\
\text { articles } \\
\text { of } \\
\text { antenna } \\
\text { I }\end{array}$} & \multirow{4}{*}{$\begin{array}{l}\text { number } \\
\text { of } \\
\text { speci- } \\
\text { mens } \\
\text { examin- } \\
\text { ed }\end{array}$} & \multirow{4}{*}{ values } & \multirow{4}{*}{$\begin{array}{l}\text { body } \\
\text { length } \\
(\mathrm{mm})\end{array}$} & \multirow{2}{*}{\multicolumn{3}{|c|}{$\frac{\text { antenna I }}{\text { peduncular articles }}$}} & \multicolumn{5}{|c|}{ antenna II } \\
\hline & & & & & & & & & \multicolumn{3}{|c|}{ peduncular articles } & \multicolumn{2}{|c|}{$\begin{array}{l}\text { flagellar } \\
\text { articles }\end{array}$} \\
\hline & & & & & & \multirow{2}{*}{$\mid \begin{array}{c}\text { length } \\
\text { III } \\
(\mathrm{mm})\end{array}$} & \multicolumn{2}{|c|}{ length ratios } & \multirow{2}{*}{$\left|\begin{array}{c}\text { length } \\
\text { IV } \\
(\mathrm{mm})\end{array}\right|$} & \multicolumn{2}{|c|}{ length ratios } & \multirow{2}{*}{$\begin{array}{c}\text { length } \\
\mathrm{I} \\
(\mathrm{mm})\end{array}$} & \multirow{2}{*}{$\begin{array}{l}\text { length } \\
\text { ratio } \\
\text { II } / I\end{array}$} \\
\hline & & & & & & & $\mathrm{I} / \mathrm{III}$ & II $/ \mathbf{I I I}$ & & III $/ \mathrm{IV}$ & $\mathrm{V} / \mathrm{IV}$ & & \\
\hline \multirow{30}{*}{$\begin{array}{c}13 \\
\text { August } \\
1969 \\
\text { St. A }\end{array}$} & \multirow[t]{16}{*}{ male } & 7 & 1 & - & - & 3.27 & 0.39 & $1.25 \mid$ & 1.26 & - & 一 & - & - \\
\hline & & \multirow[t]{3}{*}{6} & \multirow[t]{3}{*}{2} & $\max$. & 2.46 & 0.24 & 1.35 & 1.35 & 0.75 & 0.63 & 0.93 & 0.21 & 0.71 \\
\hline & & & & $\min$ & 2.44 & 0.22 & 1.25 & 1.26 & 0.51 & 0.55 & 0.87 & 0.14 & 0.58 \\
\hline & & & & mean & 2.45 & 0.23 & 1.30 & 1.31 & 0.63 & 0.59 & 0.90 & 0.18 & 0.65 \\
\hline & & \multirow[t]{4}{*}{5} & \multirow[t]{4}{*}{11} & $\max$ & 2.40 & 0.24 & 1.44 & 1.45 & 0.75 & 0.58 & 0.95 & 0.22 & 0.80 \\
\hline & & & & $\min$ & 1.80 & 0.16 & 1.14 & 1.15 & 0.40 & 0.53 & 0.60 & 0.13 & 0.54 \\
\hline & & & & mean. & 2.15 & 0.21 & 1.31 & 1.32 & 0.61 & 0.55 & 0.85 & 0.18 & 0.65 \\
\hline & & & & $s$ & 0.18 & 0.024 & 0.081 & 0.080 & 0.099 & 0.019 & 0.099 & 0.029 & 0.084 \\
\hline & & \multirow[t]{4}{*}{4} & \multirow[t]{4}{*}{28} & $\max$. & 2.10 & 0.18 & 1.61 & 1.51 & 0.57 & 0.62 & 0.96 & 0.18 & 0.90 \\
\hline & & & & $\min$ & 1.30 & 0.10 & 1.11 & 1.17 & 0.31 & 0.51 & 0.75 & 0.09 & 0.47 \\
\hline & & & & mean & 1.67 & 0.14 & 1.37 & 1.34 & 0.43 & 0.56 & 0.87 & 0.13 & 0.73 \\
\hline & & & & $s$ & 0.21 & 0.023 & 0.12 & 0.082 & 0.066 & 0.029 & 0.045 & 0.021 & 0.084 \\
\hline & & \multirow[t]{4}{*}{3} & 18 & $\max$ & 1.70 & 0.13 & 1.57 & 1.50 & 0.37 & 0.61 & 0.94 & 0.11 & 1.00 \\
\hline & & & & min. & 1.00 & 0.07 & 1.23 & 1.03 & 0.21 & 0.49 & 0.60 & 0.06 & 0.74 \\
\hline & & & & mean & 1.27 & 0.10 & 1.39 & 1.22 & 0.28 & 0.56 & 0.85 & 0.08 & 0.89 \\
\hline & & & & $s$ & 0.19 & 0.016 & 0.087 & 0.10 & 0.050 & 0.038 & 0.075 & 0.015 & 0.068 \\
\hline & female & 6 & 2 & $\max$. & 2.77 & 0.28 & 1.46 & 1.34 & 0.79 & 0.55 & 0.79 & 0.30 & 0.65 \\
\hline & & & & $\min$ & 2.54 & 0.27 & 1.36 & 1.32 & 0.76 & 0.54 & 0.78 & 0.29 & 0.64 \\
\hline & & & & mean & 2.66 & 0.28 & 1.41 & 1.33 & 0.78 & 0.55 & 0.79 & 0.30 & 0.65 \\
\hline & & 5 & 3 & $\max$ & 2.33 & 0.17 & 1.60 & 1.59 & 0.54 & 0.56 & 0.91 & 0.16 & 0.74 \\
\hline & & & & min. & 1.98 & 0.15 & 1.33 & 1.27 & 0.46 & 0.53 & 0.85 & 0.13 & 0.65 \\
\hline & & & & mean & 2.12 & 0.16 & 1.48 & 1.39 & 0.49 & 0.54 & 0.88 & 0.14 & 0.71 \\
\hline & & 4 & 44 & $\max$. & 2.23 & 0.18 & 1.55 & 1.51 & 0.52 & 0.63 & 0.94 & 0.17 & 0.95 \\
\hline & & & & $\min$ & 1.45 & 0.10 & 1.16 & 1.17 & 0.35 & 0.49 & 0.80 & 0.09 & 0.61 \\
\hline & & & & mean & 1.85 & 0.14 & 1.39 & 1.32 & 0.43 & 0.56 & 0.88 & 0.13 & 0.75 \\
\hline & & & & $s$ & 0.21 & 0.017 & 0.090 & 0.074 & 0.050 & 0.011 & 0.035 & 0.018 & 0.080 \\
\hline & & 3 & 21 & $\max$ & 1.95 & 0.14 & 1.69 & 1.45 & 0.45 & 0.60 & 0.94 & 0.15 & 0.95 \\
\hline & & & & min. & 1.25 & 0.09 & 1.22 & 1.04 & 0.27 & 0.50 & 0.82 & 0.08 & 0.66 \\
\hline & & & & mean & 1.47 & 0.11 & 1.45 & 1.31 & 0.34 & 0.54 & 0.87 & 0.10 & 0.81 \\
\hline & & & & $s$ & 0.15 & 0.014 & 0.10 & 0.096 & 0.035 & 0.027 & 0.037 & 0.013 & 0.069 \\
\hline
\end{tabular}




\begin{tabular}{|c|c|c|c|c|c|c|c|c|c|c|c|c|c|}
\hline \multirow{4}{*}{ material } & \multirow{4}{*}{$\operatorname{sex}$} & \multirow{4}{*}{$\begin{array}{l}\text { number } \\
\text { of } \\
\text { flagellar } \\
\text { articles } \\
\text { of } \\
\text { antenna } \\
\text { I }\end{array}$} & \multirow{4}{*}{$\begin{array}{l}\text { number } \\
\text { of } \\
\text { speci- } \\
\text { mens } \\
\text { examin- } \\
\text { ed }\end{array}$} & \multirow{4}{*}{ values } & \multirow{4}{*}{$\begin{array}{l}\text { body } \\
\text { length } \\
(\mathrm{mm})\end{array}$} & \multirow{2}{*}{\multicolumn{3}{|c|}{$\frac{\text { antenna I }}{\text { peduncular articles }}$}} & \multicolumn{5}{|c|}{ antenna II } \\
\hline & & & & & & & & & \multicolumn{3}{|c|}{ peduncular articles } & \multicolumn{2}{|c|}{$\begin{array}{l}\text { flagellar } \\
\text { articles }\end{array}$} \\
\hline & & & & & & \multirow{2}{*}{$\left|\begin{array}{c}\text { length } \\
\text { III } \\
(\mathrm{mm})\end{array}\right|$} & \multicolumn{2}{|c|}{ length ratios } & \multirow{2}{*}{$\mid \begin{array}{c}\text { length } \\
\text { IV } \\
(\mathrm{mm})\end{array}$} & \multicolumn{2}{|c|}{ length ratios } & \multirow{2}{*}{$\begin{array}{l}\text { length } \\
\text { I } \\
(\mathrm{mm})\end{array}$} & \multirow{2}{*}{$\begin{array}{l}\text { length } \\
\text { ratio } \\
\text { II } / \mathrm{I}\end{array}$} \\
\hline & & & & & & & $\mathrm{I} / \mathrm{III}$ & $\mathrm{II} / \mathrm{III}$ & & $\mathrm{III} / \mathrm{IV}$ & $\mathrm{V} / \mathrm{IV}$ & & \\
\hline & juvenile & 3 & 10 & $\max$ & 1.13 & 0.08 & 1.86 & 1.31 & 0.24 & 0.62 & 0.93 & 0.07 & 1.02 \\
\hline & & & & $\min$ & 0.78 & 0.04 & 1.22 & 1.05 & 0.13 & 0.49 & 0.79 & 0.04 & 0.79 \\
\hline & & & & mean & 0.88 & 0.06 & 1.46 & 1.17 & 0.19 & 0.55 & 0.86 & 0.06 & 0.94 \\
\hline . & & & & $s$ & 0.099 & 0.013 & 0.21 & 0.090 & 0.035 & 0.038 & 0.038 & 0.0086 & 0.067 \\
\hline \multirow{27}{*}{$\begin{array}{c}18 \\
\text { August } \\
1969 \\
\text { St. E }\end{array}$} & \multirow{12}{*}{ male } & \multirow[t]{4}{*}{5} & \multirow[t]{4}{*}{11} & $\max$ & 2.58 & 0.28 & 1.39 & 1.44 & 0.72 & 0.56 & 0.96 & 0.20 & 0.93 \\
\hline & & & & $\min$ & 2.09 & 0.19 & 1.11 & 1.25 & 0.58 & 0.49 & 0.71 & 0.14 & 0.56 \\
\hline & & & & mean & 2.32 & 0.22 & 1.25 & 1.35 & 0.65 & 0.53 & 0.89 & 0.17 & 0.71 \\
\hline & & & & $s$ & 0.18 & 0.028 & 0.083 & 0.059 & 0.039 & 0.022 & 0.069 & 0.015 & 0.11 \\
\hline & & \multirow[t]{4}{*}{4} & \multirow[t]{4}{*}{28} & $\max$ & 2.33 & 0.21 & 1.50 & 1.57 & 0.64 & 0.60 & 0.98 & 0.18 & 0.95 \\
\hline & & & & $\min$ & 1.50 & 0.13 & 1.07 & 1.13 & 0.39 & 0.50 & 0.80 & 0.1 .1 & 0.58 \\
\hline & & & & mean & 1.87 & 0.17 & 1.28 & 1.32 & 0.51 & 0.55 & 0.87 & 0.14 & 0.73 \\
\hline & & & & $s$ & 0.21 & 0.020 & 0.11 & 0.083 & 0.062 & 0.027 & 0.042 & 0.017 & 0.098 \\
\hline & & \multirow[t]{4}{*}{3} & \multirow[t]{4}{*}{17} & $\max$ & 1.72 & 0.15 & 1.55 & 1.40 & 0.39 & 0.64 & 0.91 & 0.12 & 0.95 \\
\hline & & & & $\min$ & 1.19 & 0.09 & 1.07 & 1.07 & 0.27 & 0.49 & 0.73 & 0.07 & 0.66 \\
\hline & & & & mean & 1.39 & 0.12 & 1.31 & 1.25 & 0.33 & 0.55 & 0.83 & 0.97 & 0.80 \\
\hline & & & & $s$ & 0.16 & 0.014 & 0.11 & 0.091 & 0.036 & 0.035 & 0.054 & 0.011 & 0.092 \\
\hline & \multirow{11}{*}{ female } & 5 & 2 & $\max$ & 2.33 & 0.19 & 1.39 & 1.34 & 0.55 & 0.56 & 0.85 & 0.16 & 0.66 \\
\hline & & & & $\min$ & 2.33 & 0.19 & 1.38 & 1.31 & 0.54 & 0.53 & 0.83 & 0.14 & 0.65 \\
\hline & & $\therefore$ & & mean & 2.33 & 0.19 & 1.39 & 1.33 & 0.55 & 0.55 & 0.84 & 0.15 & 0.66 \\
\hline & & 4 & 25 & $\max$. & 2.14 & 0.18 & 1.59 & 1.41 & 0.51 & 0.59 & 0.93 & 0.16 & 0.92 \\
\hline & & & & $\min$. & 1.52 & 0.13 & 1.20 & 1.20 & 0.35 & 0.49 & 0.70 & 0.11 & 0.64 \\
\hline & & & & mean & 1.88 & 0.15 & 1.33 & 1.30 & 0.45 & 0.55 & 0.86 & 0.13 & 0.78 \\
\hline & & & & $s$ & 0.17 & 0.013 & 0.10 & 0.061 & 0.041 & 0.029 & 0.047 & 0.015 & 0.073 \\
\hline & & 3 & 30 & $\max$ & 1.86 & 0.16 & 1.48 & 1.46 & 0.44 & 0.63 & 0.91 & 0.14 & 1.00 \\
\hline & & & & $\min$ & 1.29 & 0.10 & 1.14 & 1.15 & 0.29 & 0.48 & 0.78 & 0.09 & 0.68 \\
\hline & & & & mean & 1.49 & 1.24 & 1.32 & 1.26 & 0.35 & 0.55 & 0.84 & 0.11 & 0.81 \\
\hline & & & & $s$ & 0.11 & 0.011 & 0.082 & 0.065 & 0.073 & 0.027 & 0.027 & 0.012 & 0.075 \\
\hline & juvenile & 3 & 6 & $\max$ & 1.29 & 0.11 & 1.39 & 1.29 & 0.33 & 0.67 & 0.95 & 0.12 & 1.08 \\
\hline & & & & $\min$ & 0.88 & 0.08 & 1.00 & 1.12 & 0.20 & 0.54 & 0.80 & 0.06 & 0.91 \\
\hline & & & & mean & 1.15 & 0.10 & 1.27 & 1.22 & 0.27 & 0.60 & 0.85 & 0.09 & 0.99 \\
\hline & & 2 & 1 & - & 0.91 & 0.09 & 1.20 & 1.16 & 0.24 & 0.51 & 0.84 & 0.07 & 0.77 \\
\hline
\end{tabular}


Wakasa Bay in Japan Sea. The collections and observations in the coastal waters of Okinawa Island and Kume Island of the Ryukyu Islands, made in June and July 1970, yielded no specimen of the present species.

Systematic remarks: Although the present species appears to be a close relative of Siphonoecetes conchicola GuRJanova 1938, it differs in some characters even from the genus Siphonoecetes itself hitherto defined. Some of the definitions that have been presented for this genus by various authors are, indeed, inconsistent with one another in some essential respects and have not been fully corrected in the later references.

As regards the antenna II, for example, KR $\mathrm{K}_{\mathrm{YER}}$ (1845) mentions in his original description "Siphonoecetes, novum Amphipodum genus" only as "antennae inferiores pediformes," and SARs (1895) describes that it is furnished "with the flagellum rather short and armed at the tip with unguiform spines" (p. 609). The number of articles of the flagellum is given by STEBbing (1906) first in his statement: "Flagellum short, of 1 long and 2 short joints" (p. 682), and Chevreux and Fage (1925) adds an account of the length of articles by saying: "flag. très court à 3 art. dont le proximal beaucoup l'esemble des deux autres, quelques épines unguiformes à l'art. distal." (p. 359), but GuRJanova (1951) remarks the antenna II as with 1-2 articulated flagellum. ") BARNARD (1969), not referring to the number of article of flagellum, states: "flagellum shorter than article 5" (p. 197). By closer examination of her drawings and descriptions on the constituent species dealt with, it appears that GuRJANOva's numbering of articles is suspectedly done by omitting the 2nd article of peduncle. Even if so, these diagnoses are not quite applicable to the present species, in which the flagellum of antenna II is subequal to the 5th article of peduncle and is consisted of 2 long and 2 rudimentally short articles, bearing unguiform spines. In a figure given by HAMOND (1965) of antenna II of young Siphonoecetes dellavallei collected on the Norfolk coasts are, however, seen 2 unequal long proximal articles of flagellum, although it is not certain whether there is one small distal article in addition or two.

The definition of the uropod II recently given by BARNARD (1969) for the genus Siphonoecetes as "uropod 2 with 1-2 rami" should be taken as a correction of the former diagnoses. In the original description $\mathrm{KR}_{\mathrm{R}} \mathrm{YER}$ has given is not stated the number of ramus on uropods, but the uropods are briefly accounted for as "pedes quarti quintique pairs saltatorii; pes abdominalis sexti paris natatorius, unica instructus lamina terminali." This statement could be taken, however, as an expression of his recognition that uropods I and II differed from uropod III which was uniramous. According to Stebbing (1888, p. 1156), Boeck's (1876) definition of the subfamily Corophinae of the Corophidae, to which BoEck assigned the genera Corophium, Siphonoecetes and Glauconome, indicates of uropods as follows: "First and second uropods biramous; the rami little elongate. Third uropods small, short, broad, uniramous..... To include Cerapus, this definition will require to be modified by saying that the maxilliped

1) "1-2 члениковым жгутикам" 
are generally broad, and that the second uropods are sometimes uniramous." This again means that the genus Siphonoecetes is not characterized as having uniramous uropod II. Other diagnoses succeedingly given concerning the uropod II of Siphonoecetes run as follows: "The 2 anterior pairs of uropod biramous, with the outer ramus the longer and spinulous outside" (SARs, 1895, p. 609), "Uropod 2 similar to uropod 1, but smaller" (Stebing, 1906, p. 683), "First and second uropods biramous, with outer ramus the larger and spinulous externally" (Kunkel, 1918, p. 168), "Urop. I et II à deux branches" (Chevreux and FAGE, 1925, p. 359), or "outer margin of basal segment and outer ramus of uropods I and II armed with spines; outer ramus longer than inner"1) (GuRJanova, 1951, p. 968). These concordantly admit as a characteristic that the uropod II is biramous, to which BARNARD (1969) has evidently proposed a rather essential correction, as a result of which the present species is, as a matter of definition, rightly included in the genus Siphonoecetes.

It should undoubtedly be apparent from the descriptions allocated to the known species and that given in the present paper that the present species is distinguished from any other species of the genus Siphonoecetes, including those synonymous with others, in having the 4-segmented flagellum of antenna II and the uniramous uropod II. On the other hand, the present species is easily accessible from other species of the genus through various features, some of which are also indicated to be close one another (WALKER, 1904). It seems probable, therefore, that the present species is assigned to the genus Siphonoecetes, the difference the present species retains being of specific rank within the genus.

As has been stated elsewhere, the present species bears a close relationship with Siphonoecetes conchicola GurJanova 1938 in the similarities of general morphology and particularly of the appendages, except at least the uropod II and the antenna II. The difference in uropod II might be considered of taxonomic significance that could separate the present species from the genus Siphonoecetes and could make it near to the genus Cerapus. On the other hand, although GurJanova $(1938,1951)$ states rather vaguely that the uropod II in Siphonoecetes conchicola is similar to the biramous uropod I in the texts ${ }^{2}$, she never figures the uropod II clearly as biramous but illustrates it on one side of the body evidently as uniramous. If these figures of her were correct, these two species under comparison would be considered to form a group which is distinct from the Atlantic and Indo-Pacific groups proposed by RuFFo (1959), as referred to elsewhere. The structure of antenna II of Siphonoecetes conchicola, too, as far as is understood from the descriptions by GuRJAnova (1938, 1951), differs very much from that of the present species. On the contrary, her figures indicate that this is not justifiable and suggest that she must have overlooked the 2nd article of peduncle on description. Thus, the flagellum of antenna II, which she characterizes as 1-

1) "Наружный край базального членика и наружной ветви уроподов I и II вооружен шипани; наружная ветвь длиннее внутренней."

2) "Уроподы II короче и тоньте, чем I ; вооружепие ветвей сходно с предыдупей парой." (1951, p. 972) 
segmented, can be recognized as 2-segmented. She further figures the flagellum of antenna II as carrying, in addition to the preceding articles, a terminal claw, to which she never refers in the texts, accordingly allowing a supposition that she does not consider it as an article. In the corresponding part in the present species are clearly found 2 rudimentary short articles, that makes a difference between these two species.

Apart from the uropod II and the antenna II, most apparent differences between the present species and Siphonoecetes conchicola GuRJanova 1938 are: (1) that the antenna I reaches to the middle of 5 th article of peduncle of antenna II in the present species, whereas it does only to the end of 4th article in the latter species, (2) that 6 th articles of gnathopods I and II are armed with no and 2 spines respectively on their posterior margins in the present species, whereas these are with 3 and 4 spines respectively in the latter, (3) that the outer margin of outer ramus of uropod $\mathrm{I}$ is furnished with 4 strong spines, excluding terminal ones, and spinules over its entire length in the present species, whereas in the latter there are 4 spines only arising from its distal half, (4) that the peduncle of uropod III does not bear setae nor spines in the present species, whereas in the latter it bears setae on its postero-medial corner, and (5) that the size attains to only just over $3 \mathrm{~mm}$ in the present species, whereas it does to $8 \mathrm{~mm}$ in the latter species.

As has been discussed by Della Valle (1893), Walker (1904) or Stebbing (1910), the differences among the Atlantic species of the genus Siphonoecetes appear to be minor. Della Valle (1893) did not indeed evaluate these differences as of specific value and asserted as follows: "Per questo lato quindi il $S$. Colletti Boeck coincide col S. typicus, essendo segnato per l'uno e per l'altro che le antenne inferiori sono più brevi del corpo dell'animale. Circa poi al S. Colletti, dalla descrizione e dalla figura del BoEck è chiaro che si tratta non di una vera specie nuova, ma soltanto di un giovane del Siphonoecetes typicus Kröyer." (p. 361), "Più tardi lo stesso nome di S. cuspidatus è stato dato dallo SMITH ad un'altra n. sp. di Siphonoecetes, la quale del resto conviene perfettamente col S. typicus." (p. 362), and "A dire il vero, questi caratteri dati come distintivi della n. sp. sembrano appena sufficienti per costituire una varietà, essendo la lunghezza delle antenne, e il numero degli articoli del flagello nelle antenne anteriori molto variabili. Anche il KröYer segna queste differenze, siccome si vede confrontando i suoi disegni della Naturhist. Tidsskrift, ...." (p. 362). He thus synonymized Siphonoecetes kröyeranus BATE 1856, S. whitei BATE 1862, S. colletti B $\phi \mathrm{ECK}$ 1871, S. cuspidatus Metzger 1871, S. cuspidatus Smitr 1874 and S. pallidus SArs 1882, these were indeed all the known species at that time, with Siphonoecetes typicus KR $\phi$ YER 1845. The validity of these differences among the species of the genus Siphonoecetes was not fully admitted by Walker (1904) who "inclined to agree with Della Valle, .... so that both these species [ $=S$. colletti Boeck 1871 and S. pallidus SARs 1882], as well as the present one $[=S$. orientalis, n. sp.], might well be united to $S$. typicus" (p. 294).

Della VAlle's proposal, however, has not been actually accepted in the later 
papers treating this genus. Identities of Siphonoecetes kroyeranus BATE 1857 and $S$. whitei Gosse 1853, the latter of which was synonymized to the former by BATE and WESTWOOD (1863), seem to have been looked doubtful and are left dubious to be rightly synonymized to $S$. typicus KR $\phi$ Yer 1845 (STEBbing, 1906; Barnard, 1958), which has shown apparently localized occurrence in the arctic Greenland waters (Text-fig. 2). And most of the rest species reported for the genus have been regarded as distinct species, and for different combinations of these species keys have been proposed, in which are used these minor characters, despite Della Valle's (1893) rejection of attributing much significance to them. On the contrary, the recent reexamination of the type specimens of S. typicus KR $\phi$ YER 1845 by STEPHENSEN (1944) revealed that a few corrections were needed for KR $\phi$ YER's $(1845,1848$ ) original description as well as Stebbing's (1906) description which Stephensen considered to be made on the basis of KR $\phi \mathrm{YER}$ 's drawings, and that, although S. typicus $\mathrm{K}_{\mathrm{R} \phi \mathrm{YER}}$ 1845 is extremely close to $S$. colletti BoEck 1871, "the most important difference seems to be, that $S$. colletti has in dista! half of outer edge of peduncle of uropod 1 some short, but rather stout spines (not a series of setae), and that peduncle of uropod 3 has about 7-9 long setae, equally as long as those of ramus" (p. 132).

Stebring (1910), preceding his description of Siphonoecetes australis, n. sp., expressed himself on the genus Siphonoecetes as follows: "The known species of this genus make so near an approach one to the other,.... From Australian waters I am venturing to describe a form which seems to me independent, having a blunt rostrum, the ultimate joint of peduncle in the large second antennae longer than the penultimate, and the ramus of the third uropods not longer than broad. In this respect it agrees only with S. sabatieri, Rouville, 1894, from which, however, it is distinguished by the first uropods, and with S. smithianus, Rathbun, 1905 (a new name for S.I. Smith's pre-occupied S. cuspidatus, 1873), in which the rostrum is long, slender, acute, and the last joint of peduncle in the second antennae decidedly shorter than the preceding joint." (p. 618). When ShEARD (1936) wrote the original description of $S$. sellicki, n. sp., he gave it by emphasizing the points of difference of his species from $S$. australis Stebring 1910, that were, for example, definitely pointed rostrum, five-jointed flagellum of antenna I, the fifth joint of peraeopod IV being twice as long as broad, pleopods with inner ramus equalling two-thirds outer ramus, the peduncle of uropod III studded with five spines, etc. (p. 450), and recognized that his species was very close to $S$. smithianus Rathbun 1905. Ruffo (1959), on adding $S$. erythraeus, n. sp., to this genus, relegated S. smithianus RATHBun 1905 to a synonym of $S$. colletti BoEck 1871 and S. sellicki SHEARD 1936 to a synonym of $S$. australis Stebbing 1910, and considered that $S$. australis, $S$. orientalis and $S$. erythraeus are to form the Indo-Pacific group of species, of which he stated: "indubbiamente molto affini tra loro, caraterizzate soprattutto dalla esilità del propode negli gnatopodi del I e II paio"' (p. 33). The identities he proposed of these couples of species, which seem to be supported by BARNARD (1969), may nevertheless be problematical, since 
they are not substantiated by references to diagnostic features of the relegated species, for example, those treated by ShEARD (1939) mentioned above.

There are, as recognized easily from these cited statements, differences of opinion as to the similarity and distinction among the constituent species of the genus. Amalgamation or separation of the reported forms appears to remain still debatable and needs further discussions to support it on the basis of the actual examination of the materials representing the forms. The following diagnoses of the species are, in this regard, a tentative presentation of the position of the present species in the genus Siphonoecetes, for which here are assigned the least presently admitted species, on the basis of descriptions hitherto given on them. The diagnoses are so prepared as to arrange the species rather to reflect the relations of their geographical ranges (see Text-fig. 2), if not fully appropriate as a classification evaluating the characters of taxonomic importance.

It should be reasonably admitted that Siphonoecetes conchicola GurJanova 1938 and the present species form a relational group, despite the important difference in number of ramus on uropod II. Indeed, this difference also distinguishes sharply the present species from all other species of the genus. The difference in number of ramus is usually assigned essential significance for evaluating the systematic relationship of the species, and if this is followed in the present case, Siphonoecetes tanabensis, n. sp., should be regarded as the species distinct and differentiated alone independently from all other species of the genus, which, however, seems to me improbable as well. On the other hand, the two species, $S$. conchicola and the present species $S$. tanabensis, do not necessarily show closer similarity to other species of the Indo-west Pacific group than to the Atlantic species, with which they may be bridged by circumpolar connection. Affinities or differences hitherto stressed among the speceis of the genus are, indeed, rather interlacing and demonstrate the difficulty of considering their relationship as a whole. The number of flagellar article of antenna II has never been taken up as a diagnostic characteristic of the species of the genus. The fact that the second antenna exclusively serves as a locomotor organ in the movement over the sea bottom may offer a reason to assign some significance to the difference in its morphology.

Review of the diagnostic characters of the species of the genus Siphonoecetes KRDYER 1845:

1a. Flagellum of antenna II composed of 3 or 4 articles, of which 1st and 2nd articles are long and not rudimentally small.

2a. Uropod II biramous; 2nd article of flagellum of antenna II decidedly shorter than 1 st.

3a. Distal margins of peduncles of uropods I and II extending in lamina; outer ramus of uropod I armed with spines or spinules along its entire outer margin.

4a. Rostrum rounded; ultimate article of peduncle of antenna II longer than penultimate; antenna I reaching to distal end of 5th article of peduncle of antenna II; outer ramus of uropod I with 7 spines on its outer margin. 
.... australis Stebbing 1910: southern Australian coasts.

= sellicki SHeArd 1936 by Ruffo (1959)

4b. Rostrum pointed; antenna I not reaching to distal end of 5 th article of peduncle of antenna II.

5a. Distal laminae of peduncles of uropods I and II with serration; flagellum of antenna $I$ composed of 7-8 articles; antenna $I$ reaching to distal end of 5 th article of peduncle of antenna II. .....erythraeus RuFfo 1959: northern Red Sea.

5b. Distal laminae of peduncles of uropods I and II with fine ciliation; flagellum of antenna I composed of 14 articles; antenna I not reaching to distal end of 4th article of peduncle of antenna II.

.....orientalis WALker 1904: Ceylon, Arabian and African coasts of Indian Ocean.

3b. Distal margins of peduncles of uropods I and II not extending in lamina; outer ramus of uropod I armed with 5 spines on distal half of its outer margin; antenna $I$ exceeding distal end of 4th article of peduncle of antenna II.

.....conchicola GurJanova 1938: Petrov Island region in northern Japan Sea.

2b. Uropod II uniramous; antenna II with 4-segmented flagellum, of which 1st and 2nd articles are long and subequal in length and distal two rudimentally small; distal margins of peduncles of uropod I and II ending in extended fine serration ventrally; outer ramus of uropod I armed with 4 bifurcate strong spines (excluding terminal ones) and spinules over its entire dorsolateral surface; ultimate article of peduncle of antenna II shorter than penultimate; inner expansion of peduncle of uropod III devoid of setae or spines.

.....tanabensis, n. sp.: southern Japanese coasts.

1b. Flagellum of antenna II composed of 2 or 3 articles, of which 1 st article is long and is carrying distal rudimentally small articles on its apex; uropod II biramous.

6a. Posterior (grasping) margins of 6 th articles of gnathopods I and II armed with 3 and 6 spines respectively; distal lamina of peduncle of uropod II with serration; antenna I exceeding distal end of 4th article of peduncle of antenna II; rostrum longer than lateral lobe and pointed.

7a. Outer margin of peduncle of uropod I furnished with some setae only; inner expansion of peduncle of uropod III furnished with traces of setae; distal lamina of peduncle of uropod I with serration; outer ramus of uropod I with 11 spines on its outer margin.

.....typicus KR $\phi$ Yer 1845: south-west Greenland coasts.

non typicus BAte and Westwood 1863 by Stebbing (1906). non typicus Della Valle 1893 (in part) by Stebbing (1899).

$7 \mathrm{~b}$. Outer margin of peduncle of uropod I armed with some short, stout spines 
distally; inner expansion of peduncle of uropod III carrying about 7-9 long setae; distal lamina of peduncle of uropod I without serration; outer ramus of uropod I with 5-6 spines on its outer margin.

.....colletti BoEgK 1871: European and American coasts of Atlantic Ocean, North Sea, and Guinea coasts of west Africa.

6b. Posterior (grasping) margins of 6th articles of gnathopods I and II armed with 2 and 5 spines respectively; inner expansion of peduncle of uropod III carrying setae or spines.

8a. Distal laminae of peduncles of uropods I and II not developed and straight; outer ramus of uropod I with 8 spines on its outer margin; peduncle of uropod I armed with some spines on its outer margin; antenna I not reaching to distal end of 4th article of peduncle of antenna II; rostrum shorter than lateral lobe and pointed.

....pallidus SARs 1882: south-west Norway coasts.

8b. Distal laminae of peduncles of uropods I and II provided with ciliation; outer ramus of uropod I with 4 spines on its outer margin; peduncle of uropod I armed with a few spines on its outer margin; antenna I not reaching to distal end of 4th article of peduncle of antenna II; rostrum longer than lateral lobe and pointed.

.....dellavallei Stebring 1899: Mediterranean Sea and Norfolk coasts of North Sea.

=typicus Della Valle 1893 (in part) by Stebbing (1899).

8c. Distal laminae of peduncles of uropods I and II armed with serration; outer ramus of uropod I with 6 spines on its outer margin; peduncle of uropod I without spines on its outer margin; antenna I exceeding distal end of 4th article of peduncle of antenna II; rostrum shorter than lateral lobe and pointed. .... sabatieri DE Rouville 1894: French coast (lagoon) of Mediterranean Sea (and Guinea coasts of west Africa).

Habitat: Adult individuals of Siphonoecetes tanabensis, n. sp., are, in summer months of July to September when the observations have been made, exclusively found crawling with their nests on the shallow sea bottom. They have never been seen swimming out of their nests in their natural habitat. When, however, they are captured in glass bowls in the laboratory, many of them come out of their nests and swim actively around in the water. As they swim, they take the posture of extending the body straightly and the antennae forward, and move forward with the aid of pleopods. On the contrary, when they crawl carrying with their nests over the bottom, they move backward by kicking the bottom forward with their powerful antennae I.

The preliminary results of examination of series of quantitative collections, which were taken in August 1969 at Stations A-E in Tanabe Bay, reveal that the distribution 
of the species is mostly limited in extent to the sea bottom shallower than about 5 metres at the low tide. The abundant populations have been recorded from the depths of 3 to 4 metres at Stations A, B and D, and from the depths of 1.5 to 2.5 metres at Station E, whereas the species retains its abundance over the depths from 0.5 to 4 metres at Station G.

Considerable place-to-place variations in population density is, however, notice-
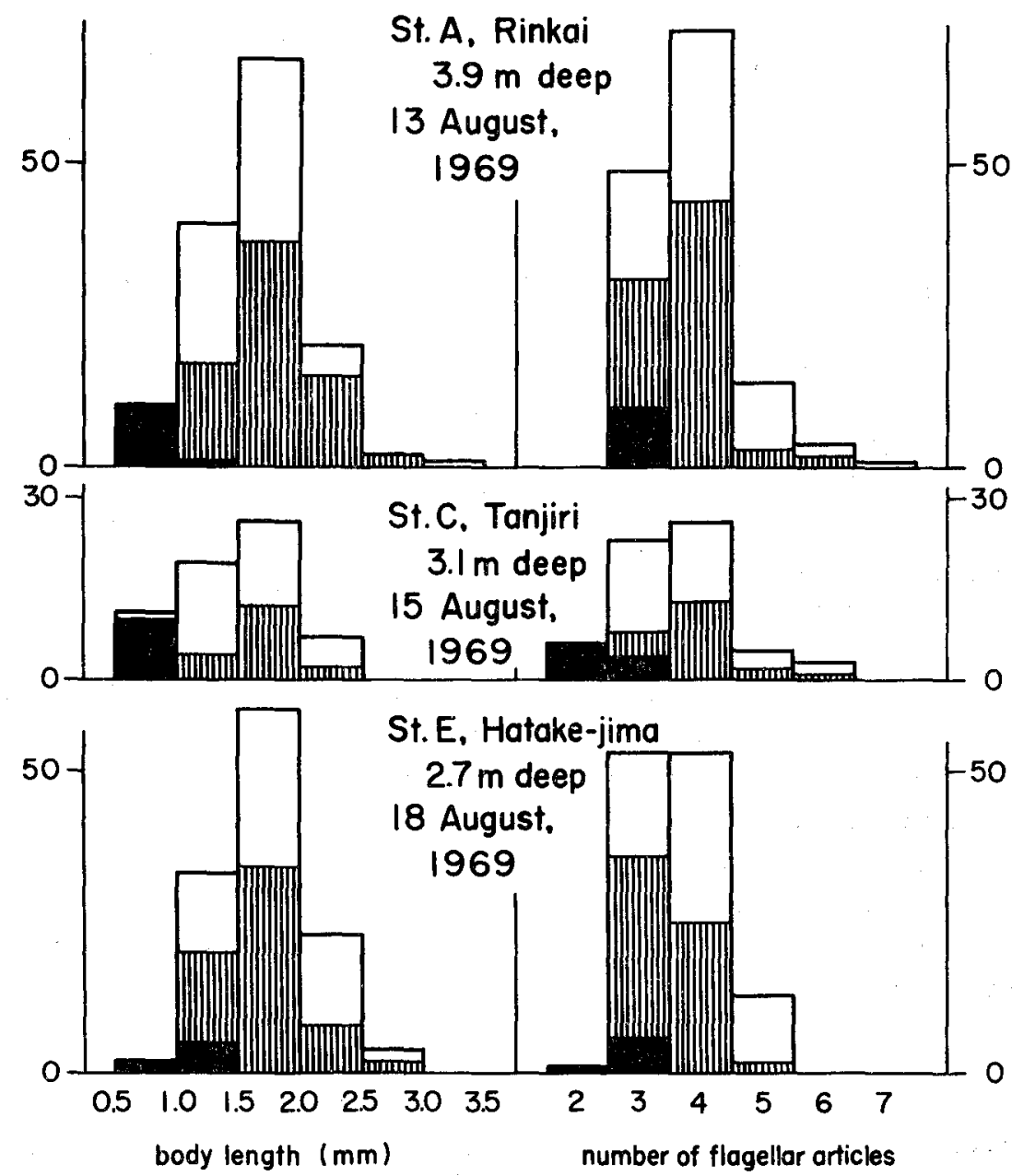

Text-fig. 10. Population compositions for different populations of Siphonoecetes tanabensis, analysed on the basis of size and number of flagellar articles of antenna $I$.

able. For example, within a set of 5 samples, which were collected from a depth of $3.9 \mathrm{~m}$ (calculated to the standard sea level) at Station A on August 13, 1969, the population density varies from 48 to 145 individuals (88.8 \pm 40.6 individuals) per $5 \times 5 \mathrm{~cm}^{2}$. The highest value of population density of 221 individuals per $5 \times 5 \mathrm{~cm}^{2}$ 

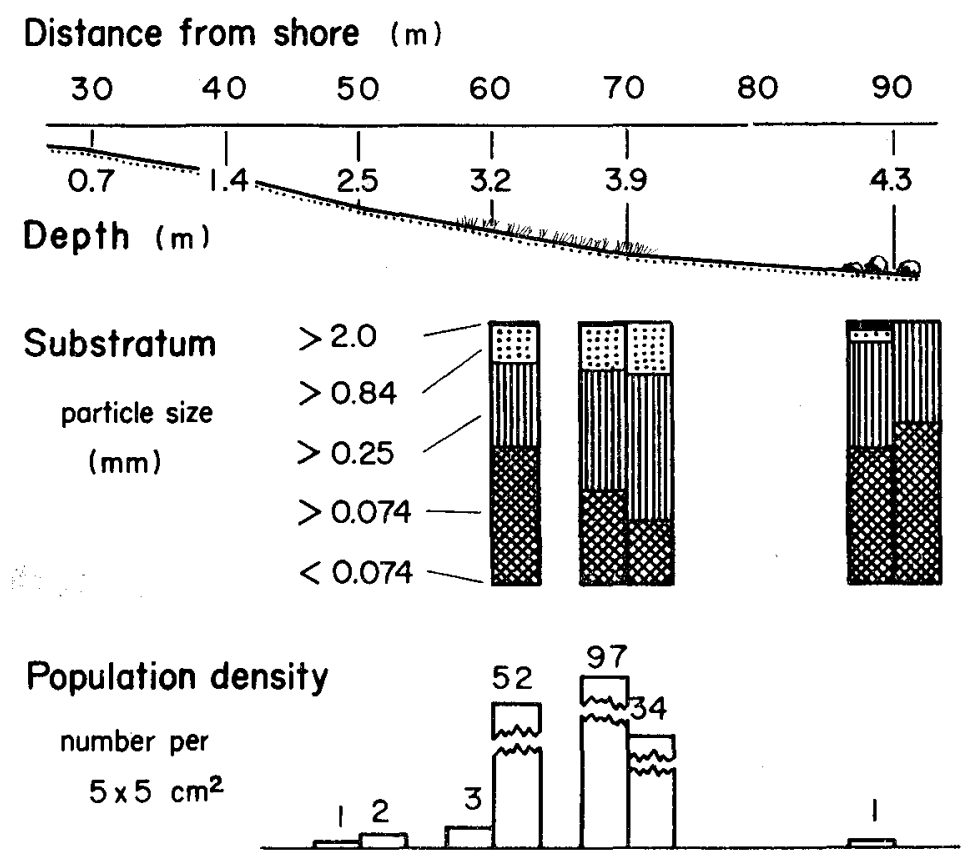

Text-fig. 11. The variation in population density of Siphonoecetes tanabensis along a transect of sea bottom at St. A, surveyed on 14 August, 1969. Fractional percentage distributions of substrata are also shown.

has been recorded from a depth of $2.0 \mathrm{~m}$ at Station C on August 15, 1969, whose figure is equivalent to 88,400 individuals per $1 \mathrm{~m}^{2}$ or nearly 9 individuals per $1 \mathrm{~cm}^{2}$. With these levels of population density, this amphipod is the dominant species of the animal community of the sea bottom there obviously in quantity, and sometimes perhaps in number as well. The substrata where the species is found and the higher levels of its population density are recorded are generally fine sand (Text-fig. 11), although the preliminary analyses of the substrata do not indicate close correlation between the particle size distribution of the substratum and the population density.

\section{Riassunto}

Viene descritta una nuova specie, Siphonoecetes tanabensis, raccolta lungo le coste del Golfo di Tanabe e la costa orientale del Shikoku. I caratteri più tipici della questa specie che si avvicina maggiormente a $S$. conchicola sono: il II paio di uropodi con un solo ramo e il flagello del II paio di antenne composto di 2 lunghi articoli e 2 altri articoli brevi e rudimentali. Anche questa specie differisce dalle altre specie, e particolarmente da S. conchicola, per i seguenti caratteri: l'assenza delle robuste spine palmare nel I paio di gnatopodi, la presenza di 2 robuste spine palmare nel II paio di gnatopodi, il ramo esterno del I paio di uropodi armato, Iungo tutto il margine 
esterno, di circa 4 grosse spine e i piccole spine, e la completa assenza delle spine e le setole nel peduncolo del III paio di uropodi.

Le diagnosi date dai vari Autori al genere Siphonoecetes e alle sue specie sono state studiate, e i dati riguardanti le loro distribuzioni geografici sono state riportati in una figura; si possono notare tre gruppi morfologici e geografici per le loro. La tavola delle diagnosi è stata novamente proposta per le specie del genere Siphonoecetes perche $S$. tanabensis si distingue dalle altre specie.

Gli individui di questa specie sono state trovate con una abbondanza esclusivamente nelle pescate eseguite nel fondo di sabbia alla profondità compressa tra i $0.5 \mathrm{e}$ i $5 \mathrm{~m}$. I massimi valori riscontrati raggiungono i 221 individui per $5 \times 5 \mathrm{~m}^{2}$.

\section{REFERENGES}

Barnard, J.L. 1958. Index to the families, genera, and species of the gammaridean Amphipoda (Crustacea). Allan Hancock Found. Publ., Occ. Paper, No. 19, pp. 1-146.

— 1965. Marine Amphipoda of atolls in Micronesia. Proc. U.S. Nat. Mus., Vol. 117, no. 3516, pp. 456-552.

- 1969. The families and genera of marine gammaridean Amphipoda. Smithonian Inst., U.S. Nat. Mus., Bull. 271, pp. i-vi-1-535.

Barnard, K.H. 1916. Contributions to the crustacean fauna of South Africa. 5. The Amphipoda. Ann. S. Afr. Mus., Vol. 15, no. 3, pp. 105-302, Pls. 26-28.

— 1937. Amphipoda. The John Murray Exped. 1933-34 Sci. Rept., Vol. 4, no. 6, pp. 131-201.

Bate, C.S. 1857. A synopsis of the British Edriophthalmous Crustacea. Ann. Mag. Nat. Hist., Ser. 2, Vol. 19, pp. 135-152.

Bate, C.S. \& Westwood, J.O. 1863. A History of the British Sessil-eyed Crustacea. Volume 1. John Van Voorst, London. 507 pp.

BoEck, A. 1870. Crustacea amphipoda borealia et arctica. Forhandl. Vidensk.-Selsk. Christiania, 1870, pp. $83-280+$ i-viii.

- 1876. De skandinaviske og arktiske Amphipoder, beskrevne af Axel Bozck. Andet Hefte. Efter Forfatterens D $\phi$ d udgivet ved Hakon BoEck, Christiania, 1876, pp. 161-713.

Gerevreux, E. 1900. Amphipodes provenant des campagnes de l'Hirondelle (1885-1888). Rés. Campagnes Sci. Albert Ier Monaco, Vol. 16, pp. i-iv+1-195, Pls. 1-18.

Chevreux, E. \& Fage, L. 1925. Amphipodes. Faune de France, Vol. 9, Paul Lechevalier, Paris. 488 pp., 438 text-figs.

Della Valle, A. 1893. Gammarini del Golfo di Napoli. Fauna und Flora des Golfes di Neapel, Vol. 20, pp. 1-948, Atlas, Explanation of Plates and Plates 1-61.

Gurjanova, E. 1938. Amphipoda, Gammaroidea of Siauku Bay and Sudzukhe Bay (Japan Sea). Rept. Japan Sea Hydrobiol. Exped. Zool. Inst. Acad. Sci. USSR, 1934, Pt. 1, pp. 241-404. (in Russian)

— 1951. Bokoplavy morej SSSR is sopredel'nykh vod (Amphipoda-Gammaridea). Opred. po Faune SSSR, Akad. Nauk SSSR, Vol. 41, 1029 pp., 705 text-figs. (in Russian)

HAMOND, R. 1965. On some amphipods from the coast of Norfolk. J. mar. biol. Ass. U.K., Vol. 45, no. 1, pp. 153-160.

Harada, E. 1969. On the interspecific association of a snapping shrimp and gobioid fishes. Publ. Seto Mar. Biol. Lab., Vol. 16, no. 5, pp. 315-334.

KR $\phi_{\text {YER, H. }}$ H. 1845. Karcinologiske Bidrag. Naturhistorisk Tidsskrift, NR, Vol. 1, pp. 283-345, Pls. 1-3 \& pp. 403, 453-638, Pls. 6-7.

- - 1842-1848. Voyages de la commission scientifique du Nord; en Scandinavie, en Laponie, au Spitzberg et aux Ferö, pedant les années 1838-1840, sur la corvette la Recherche, commandée par M. Fabre. Publiés par ordre du Roi sous la direction de M. Paul Gaimard. 17 Vols. Paris, 
$1842-1848$.

Kunkel, B.W. 1918. The Arthrostraca of Connecticut. Bull. Conn. State Geol. N.H. Survey, Hartford, No. 26, pp. 1-261.

Meadows, P.S. 1964. Substrate selection by Corophium species; the particle size of substrates. J. Anim. Ecol., Vol. 33, pp. 387-394.

1964. Experiments on substrate selection by Corophium volutator (Pallas): depth selection and population density. J. exp. Biol., Vol. 41, pp. 677-687.

Metzger, A. 1871. Die wirbellosen Meeresthiere der ostfriesischen Küste. Zweiter Beitrag. Ergebnisse der im Sommer 1871 unternommenen Excursionen. 21ster Jahresb. Naturhist. Gesellsch. Hannover. Amphipoda on pp. 28-32.

Rathbun, Mary J. 1905. Fauna of New England. 5. List of the Crustacea. Occ. Papers of the Boston Soc. Nat. Hist., No. 7, pp. 1-117.

REID, D.M. 1951. Report on the Amphipoda (Gammaridea and Caprellidea) of the coast of tropical west Africa. Atlantióe Rept., No. 2, pp. 189-291.

De Rouville, M.E. 1894. Sur un Amphipode nouveau de Cette. G.-R. Ass. France, Sess. 23, Vol. 1, p. 173 .

Rufro, S. 1959. Contributions to the knowledge of the Red Sea. No. 13. Contributo alla conoscenza degli anfipodi del Mar Rosso (1) (Materiali raccolti a Ghardaqa e nel Golfo di Aqaba). Sea Fish. Res. Sta., Haifa, Bull. No. 20, pp. 11-36.

Sars, G.O. 1895. Amphipoda. An Account of the Crustacea of Norway, I, Texts, pp. i-vii $+1-711$, Plates, Pls. 1-240+Suppl. Pls. 1-8.

SheArd, K. 1936. Amphipoda from a South Australian reef. Part I. Rec. South Austr. Mus., Vol. 5, pp. 445-455.

Stebing, T.R.R. 1888. Report on the Amphipoda collected by H.M.S. "Challenger" during the years 1873-76. Rept. Sci. Res. Voy. Challenger, Zool., Vol. 29, Text, pp. 1-1737, Plates, Pls. $1-210$.

1899. Revision of Amphipoda. Ann. Mag. Nat. Hist., Ser. 7, Vol. 3, p. 350.

1899. On the true Podocerus and some new genera of amphipods. Ann. Mag. Nat. Hist., Ser. 7, Vol. 3, pp. 237-241.

_-_ 1906. Amphipoda. I. Gammaridea. Scrulze's "Das Tierreich", Lief. 21, Walter de Gruyter, Berlin. xxxix +806 pp., 127 text-figs.

— 1910. Scientific results of the trawling expedition of H.M.C.S. "Thetis". Crustacea, Pt. V. Amphipoda. Mem. Austr. Mus., Vol. 4, Pt. 12, pp. 567-658, Pls. 47-60.

Stephensen, K. 1942. The Amphipoda of N. Norway and Spitzbergen with adjacent waters. Troms $\phi$ Mus. Skrifter, Vol. 3, Pt. 4, pp. 363-526.

— 1944. Amphipoda. The zoology of East Greenland. Medd. Gr $\phi$ nland, Momm. Videns. Unders $\phi$ gel., Vol. 121, no. 14, pp. 1-165.

Verrill, A.E. \& Smith, S.I. 1874. Report upon the invertebrate animals of Vineyard Sound and adjacent waters, with an account of the physical features of the region. Report of Professor S.F. BAIRD, Commissioner of Fish and Fisheries, on the condition of the sea-fisheries of the South Coast of New England in 1871 and 1872.

Walker, A.O. 1904. Report on the Amphipoda collected by Professor Herdman, at Ceylon, in 1902. Geylon Pearl Oyster Fish. Suppl. Rept., No. 17, pp. 229 300, Pls. 1-8. 